\title{
ANTHROPOMETRIC AND SOMATOTYPE CHARACTERISTICS OF RACERS IN DIFFERENT SKI EVENTS
}

\author{
Bogdana Ilinova, Maria Toteva.
}

Key words: Body structure, somatotype, ski-racers

Body structure, form and dimensions are closely related to human motor functions. They are a morphological predisposition for the achievement of high performances in different sports. The successful presentation in the certain sport depends on wide variety of factors and part of them are a proper morphological structure, body composition and somatotype of the athletes from the corresponding sport. The interconnection between the structure of the body and its functional abilities plays a significant role in the training process for obtaining the best sports results.

Anthropometry has been widely used by different researchers to clarify variations in body profiles between numerous sports. (Reilly et al. 1990; Wilber \& Pitsiladis, 2012). Physical characteristics and body structure of young athletes are also important criteria for coaches (Mildner et al. 2010). The somatotype, being a quantitative description of the present shape and composition of the human body may be used as a tool for sport selection among young athletes (Carter \& Heath, 1990; Groshev \& Toteva, 2002) and even within the same sport individual anthropometric characteristics are related to athlete's performance level. This makes the evaluation of the anthropometry in the athletic population very interesting in order to describe the best body profiles for the certain sport.

\section{Material and methods}

An anthropometric investigation of male ski racers, participating in different ski events was done. The athletes included in the present study were divided in the following three groups. 35 down-hill racers at mean age 22,3 years, 30 cross-country racers at mean age 21,5 years, and 25 ski jumpers at mean age 21,2 years.

Several anthropometric variables, needed for calculating of somatotype components (Carter, 2002) were collected. Body height was measured to the nearest $0,1 \mathrm{~cm}$ with Martin anthropometer. Body weight was determined with electronic body weight scale with accuracy up to 200 grams. Body Mass Index was calculated. Upper arm, tight and calf circumferences were measured, using plastic measuring type to the nearest $0,1 \mathrm{~cm}$. The skinfolds were measured using Lange skinfold caliper with an accuracy up to $0,1 \mathrm{~cm}$. Bi-epicondilar humerus and femur breaths were measured with bone caliper, accurate up to $0,1 \mathrm{~cm}$. Over the measured parameters somatotype components (endomorphy, mesomorphy and ectomorphy) were calculated. (Carter \& Heath, 1990; Carter 2002)

The data were submitted to a statistical processing by means of the variation analysis

\section{Results and discussion}

Ski racers are of middle stature. The greatest high value being found in cross-country skiers $(176,8 \mathrm{~cm})$, followed by the values obtained from down-hill $(173,4 \mathrm{~cm})$ and ski jumping racers $(172,8 \mathrm{~cm})$. The difference in the height between the last two groups is not statistically significant. Racers in ski jumping indicate the heaviest body weight $(72,8 \mathrm{~kg})$. Similar values are found in down-hill racers $(71,8 \mathrm{~kg})$. Cross-country skiers are with lowest mean values of body weight $(70 \mathrm{~kg})$.

The circumferences of the lower extremities, and especially the tight, show the lowest measures in cross-country skiers, due to the biomechanics of the event. The arm circumferences of the same group also indicate the lowest values. This fact can be explained by the cyclic movement of the upper extremities and the prevailing participation of the extensor muscles, which does not permit a considerable muscle hypertrophy to be developed. The bone diameters of the extremities attest to a good skeleton development in all ski racers. Some par- 
ticular morphological specificities however were found in skiers, practicing the respective event the down-hill racers have the largest elbow diameters, the ski jumpers - the greatest knee diameters, and the cross-country racers have the lowest values for the observed bone diameters. The sum of the skinfolds proves to be the lowest in cross-country skiers and the respective values obtained from ski jumping and down-hill racers were almost equal. The character of the physical loading in the par- ticular ski event leads to a specific localization of the fat tissue. The lowest values for fat tissue were obtained from the lower extremities of the competitors in ski jumping and from the upper extremities of the down-hill racers

The observed parameters allow to draw up a somatotype characteristics of the racers in the respective events. (Table1)

Table 1: Body Height, Body Weight, BMI and Somatotype of Skiers, Participating in Different Ski Events.

\begin{tabular}{|c|c|c|c|c|c|c|c|}
\hline & & $\begin{array}{l}\text { Body Height } \\
(\mathrm{cm})\end{array}$ & $\begin{array}{l}\text { Body Weight } \\
(\mathrm{kg})\end{array}$ & BMI & Endomorphy & Mesomorphy & Ectomorphy \\
\hline $\begin{array}{l}\text { Down - hill } \\
\text { racers }\end{array}$ & $\begin{array}{l}\bar{X} \\
S\end{array}$ & $\begin{array}{c}173,4 \\
4,8\end{array}$ & $\begin{array}{l}71,8 \\
5,09\end{array}$ & $\begin{array}{c}23,88 \\
1,9\end{array}$ & $\begin{array}{l}2,56 \\
1,09\end{array}$ & $\begin{array}{l}6,16 \\
1,12\end{array}$ & $\begin{array}{c}1,9 \\
0,98\end{array}$ \\
\hline $\begin{array}{l}\text { Cross - country } \\
\text { skiers }\end{array}$ & $\begin{array}{l}- \\
\text { X } \\
\text { S }\end{array}$ & $\begin{array}{c}176,8 \\
3,9\end{array}$ & $\begin{array}{c}70,0 \\
5,0\end{array}$ & $\begin{array}{c}21,78 \\
0,9\end{array}$ & $\begin{array}{l}2,05 \\
0,83\end{array}$ & $\begin{array}{l}5,36 \\
0,71\end{array}$ & $\begin{array}{c}2,7 \\
0,69\end{array}$ \\
\hline Ski - jumpers & $\begin{array}{l}\bar{X} \\
S\end{array}$ & $\begin{array}{c}172,8 \\
5,7\end{array}$ & $\begin{array}{c}72,9 \\
5,3\end{array}$ & $\begin{array}{c}24,46 \\
1,2\end{array}$ & $\begin{array}{l}2,50 \\
0,98\end{array}$ & $\begin{array}{l}6,50 \\
0,91\end{array}$ & $\begin{array}{c}1,7 \\
0,81\end{array}$ \\
\hline
\end{tabular}

Endomorphy, characterizing the relative part of the fat tissue, is moderately expressed in ski racers. The endomorphy component in cross-country racers indicates considerably lower rations $(2,05)$, while in down-hill racers and in ski jumpers are as follows 2,56 , and 2,50, which are almost equal.

Mesomorphy is the leading component in skiers, which exhibits a good muscle-skeleton development. It is most expressed in ski jumpers $(6,50)$, not very much different in down-hill racers $(6,16)$ and considerably lower in cross-country racers $(5,36)$. The best qualified racers indicate the highest mesomorphy components, which gives us enough reason to assume that it is the main morphological predisposition for a good physical working capacity.

Ectomorphy is most clearly expressed in cross-country skiers due to the longer body proportions and the high values of the relation height/weight.

An endo-mesomorphic somatotype was established in down-hill racers with values $2,56-6,16-1,9$. Similar are the ratings obtained from ski jumpers 2,50 $6,50-1,7$. The most homogenous with regard to body structure is the group of cross-country skiers which exhibit an ecto-mesomorphyc somatotype 2,05-5,36-2,7. The mean somatotype evaluations for each event are presented on fig.1.

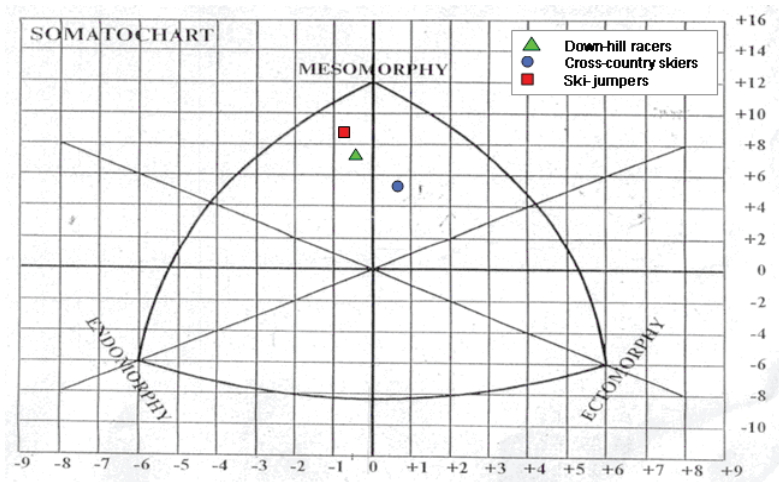

Fig. 1 Mean somatotype of racers participating in different ski events

The estimated parameter SDD (critical value 2,0) indicates statistically significant differences between the somatotypes of cross-country skiers and of the racers in the other two events.

Our findings correspond to these of Chovanova (1979) and Orvanova (1987), and White \& Johnson (1991)

In an interesting study Vermeulen et al. (2017), investigating body characteristics of elite alpine skiers, devided in TECH (Slalom and Giant Slalom) and SPEED (Super Giant Slalom and Downhill) events found an edno-mesomorphic somatotype with mean values $2,8-5,6-1,8$ for TECH racers and $3,1-6,4-1,4$ for SPEED racers. This data concurs to 
our findings in concern to samototypic characteristics of down-hill skiers. But the investigated from Vermeulen et al. (2017) elite alpine skiers are taller and heavier than our down-hill skiers. A heavy body profile is beneficial in alpine skiing, because it helps overcome frictional forces through a higher amount of potentional energy (Gilgien et al. 2013). Body mass, preferably in the form of high muscularity is an important factor of success in elite alpine skiers, while a certain degree of body fatness can be functional as it may support the effect of gravity.

Taeymans et al. (2011) also found and edno-mesomorphic somatotype of alpine skiers 2,93-6,031,58

\section{Conclusions}

The following conclusions can be drawn from our investigation:

The racers in the observed ski events show specific structural features.

Down-hill and ski jumping racers exhibit a similar endo-mesomorphic somatotype.

Cross-country skiers have ecto-mesomorphic somatotype, differing significantly from the somatotypic characteristics of the other two events.

Mesomorphy in ski racers is very well expressed and it can be considered as a morphobiological predisposition for a good physical working capacity.

\section{References}

Carter \& Health B (1990). Somatotyping - Development and Applications Press syndicate of the University of Cambrige (vol.5) New York.
Carter L (Ed) (2002) The Heath - Carter Anthropometric Somatotype ( $2^{\text {nd }}$ ed.) San Diego, Ca.

Choranova E (1979) Phisique of Top Ice Hockey Players and skiers and its Relation to Their Specialisation. Collegium Anthropologicum, 3, 189-193.

Gilgien M, Sporry I, Kroll I, Chardonnens I, \& Erich M (2013) Determination of External Forces in Alpine Skiing Using a Differential Global Navigation Satelite System, Sensors, 13, 9821-9835.

Groshev O, Toteva M (2002), Age Reculiarities in the Somatotype Characteristics of Adolescent Skiers, Sport Science 3, 78-82.

Mildner E, Barth M, Erin G, Kriebernegg R, Standacher A \& Raschner C. (2010) Relationship between physical fitness, ski - technique and racing results of young alpine ski racers, $5^{\text {th }}$ Int. Congr. on Science and skiing, p 23, Austria.

Orvanova E (1987) Physical Structure of Winter Sports Athletes, Journal of Sports Sciences, 5, 197-248.

Relly T, Secher N, Snell P \& Williams C. (1990), Physiology of sports. E \& FN Sport.

Taeymans J, Aerenhonts D, Clijsten R, Fassler R, Clanys P \& Baeyens J. (2010) Somatotype and Kinanthropic Characteristics of Male and Female Junior and Elite Senior Alpine Skiers, $5^{\text {th }}$ Int. Congr. on Science and skiing (Austria) p. 452-460

Vermeulen B, Clijsen R, Fassler R, Taeymans J, D'Hondt E \& Aerenhonts D (2017) Event Specific Body Characteristics of Elite Alpine Skiers in Relation to International Rankings, Advances in Anthropology, 7, 94-106.

White A \& Johnson S (1991) Phisiological Comparison of International and Regional Alpine skiers. International Joutnal of Sports Medicine, 12, 374-378.

Wilber R \& Pitsiladis Y (2012) Kenyan and Ethiopian Distance Runners What Makes them so Good? International Journal of Sports Physiology and Performance, 7, 92-102.

Bogdana Ilinova MD PhD

Assoc. Professor Dep. of Sports Medicine

National Sports Academy „Vassil Levski”, Sofia, Bulgaria. e-mail: bogyilinova@abv.bg

Maria Toteva MD DSc Professor

National Sports Academy „Vassil Levski”, Sofia, Bulgaria. 